\title{
Why Monitor Violent Websites? A Justification*
}

\author{
Raphael Cohen-Almagor ${ }^{1}$, Sharon Haleva-Amir ${ }^{2}$ \\ ${ }^{1}$ University of Hull, Hull, UK; ${ }^{2}$ Faculty of Law, University of Haifa, Haifa, Israel. \\ Email: R.Cohen-Almagor@hull.ac.uk, sharoni.haleva.amir@gmail.com
}

Received April 16 ${ }^{\text {th }}$ 2012; revised May 15 ${ }^{\text {th }}, 2012$; accepted May 26 ${ }^{\text {th }}, 2012$

\begin{abstract}
The authors argue that the international community should continue working together to devise rules for monitoring specific Internet sites, as human lives are at stake. Preemptive measures could prevent the translation of murderous thoughts into murderous actions. Designated monitoring mechanisms for certain websites that promote violence and seek adherents for the actualization of murderous thoughts could potentially prevent such unfortunate events. Our intention is to draw the attention of the international community's multi-agents (law-enforcement agencies, governments, the business sector, including Internet Service Providers, websites administrators and owners, civil society groups) to the urgent need of developing monitoring schemes for certain websites, in order to prevent violent crimes.
\end{abstract}

Keywords: Internet Monitoring; Violent Websites; Dawson College Massacre; Jokela High School Massacre; Internet Governance; Kimveer Gill; VampireFreaks.com; Virginia Tech Massacre; Red Lake High School Massacre

\section{Introduction}

When the idea of the Internet was first conceived by visionaries such as Vannevar Bush [1], Joseph Carl Robnett Licklider [2], Douglas Engelbart [3], Vint Cerf [4], Robert W. Taylor [5], Ted Nelson ${ }^{1}$, Larry Roberts ${ }^{2}$, Robert E. Kahn ${ }^{3}$, Leonard Kleinrock [6] and Paul Baran [7], they could not have imagined the present fascinating state of the Internet. The rich and diversified nature of the Internet and its wide circulation has benefited millions of users around the world. The Net serves as a communication medium comprising all other media. It is an arena for a wide array of public debates, social networks, an infrastructure for digital commercial activities, and a megasized information bank [8]. The Internet can be used for positive purposes as well as for negative and wicked purposes.

One of the ways to confront the dangers of boundless speech over the web is by monitoring such dangerous, anti-social websites as well as ones that are likely to be

\footnotetext{
*We are grateful to Janet Spikes, Carly Nuzbach and Nick Mills for their most valuable assistance. This is an elaborated and updated version of "Bloody Wednesday in Dawson College-The Story of Kimveer Gill, or Why Should We Monitor Certain Websites to Prevent Murder," Studies in Ethics, Law and Technology, Vol. 2, No. 3, Article 1 (December 2008).

${ }^{1}$ http://www.livinginternet.com/w/wi_nelson.htm

${ }^{2}$ Dr. Lawrence G. Roberts, http://www.ziplink.net/ lroberts/ http://www.packet.cc/; Larry Roberts, Internet Pioneers http://www.ibiblio.org/pioneers/roberts.html

${ }^{3}$ Robert Kahn-TCP/IP Co-Designer,

http://www.livinginternet.com/i/ii_kahn.htm; Robert E. Kahn

http://www.greatachievements.org/?id=3749
}

used for creating social support groups for potential criminals. The idea is not to implement surveillance of the entire Internet, something that we oppose on princepled, free speech grounds, but to monitor the areas of the Internet that are potentially harmful in order to detect and forestall crimes. This paper focuses on the story of Kimveer Gill, a 25-year-old man from Laval, Montreal who wished to murder young students at Dawson College. We argue that the monitoring of certain sites on which criminals voice their violent goals could potentially prevent unfortunate events like this particular incident. We do not support censorship of the Internet, nor do we aim to induce moral panics ${ }^{4}$ [9-13] among Internet users because we do not see the Internet as "a threat to societal values and interests" [9]. Technology is not the problem. The problem is created by individuals who abuse technology to advance criminal agendas. Indeed, the Internet is a useful platform that has changed daily life forever and is here to stay, but we must devise ways to deal with its less positive aspects. Our intention is to draw the attention of governments, law-enforcement agencies and civil society groups - to the urgent need of developing monitoring schemes for potentially problematic websites,

\footnotetext{
${ }^{4}$ Moral Panic is a sociological term coined by Stanley Cohen. The term refers to the reaction of a group of people based on a false or exaggerated perception that a cultural phenomenon, behavior or group (mostly minority group or subculture) is dangerously deviant and poses a threat to society. An important factor in moral panic is the deviancy amplification spiral-an increasing cycle of media reports on undesirable events or behaviors which induce moral panics in society and can lead to legislation designed to further penalize those established as the threatening deviants who are the source of the panic.
} 
in order to prevent homicide. Our expectation for international cooperation by all segments of society is not based on any existing legal obligations but rather upon the moral obligations that cross borders and cultures regarding the sanctity of life and the urgency to save lives and prevent crimes. The Internet business sector (Internet Service Providers, websites administrators and owners) bears an even heavier responsibility, since the moral obligations imposed on it may in due course become a legal obligation as was the case with regard to child pornography and Cybercrime ${ }^{5}$ [14]. By "potentially problematic websites", we refer to websites that attract criminals to post their criminal ideas and criminal intentions. Lawenforcement agencies are acquiring experience and understanding of social networking on the Internet. Their work facilitates flexible schemes for identifying those websites and how criminals are using them. Analyzing several case studies, most notably the Kimveer Gill episode and Vampire-Freaks.com, the site which hosted his murderous thoughts, we argue that if the police had monitored this site as well as other such known sites on a regular basis, bloodshed could have been prevented.

\section{The Murderous Attack}

On the morning of September 13, 2006, Kimveer Gill, dressed in black combat boots, a black Matrix style trench coat and armed with three guns, drove his black car to downtown Montreal with the aim to kill. Gill walked past the Dawson Daycare Center, which daily oversees 48 toddlers, along a busy street-the Maisonneuve. Gill disliked cigarettes, and when he saw some students smoking outside the college main entrance he shot two of them. Then he went inside to the atrium. It was lunchtime; many students filled the cafeteria as Gill began shooting at random with his semi-automatic weapon $[15,16]$. He killed 18-year-old Anastasia Rebecca De Sousa, a Dawson college student, and injured at least 20 people (four of them were hospitalized in critical condition) [17]. The gunman showed no mercy for wounded Anastasia and refused to allow a fellow student to help her. Her autopsy revealed she was shot nine times at close range [18].

Kimveer Gill took hostages and used them as human shields while the police were pursuing him. During the gunfire exchange, the gunman was hit in the arm. He then committed suicide by shooting himself. This dramatic chain of events took less than 10 minutes from beginning to end $[19,20]$.

Gill had no known connection to Dawson College, the largest college in downtown Montreal. Unlike other universities in the city, it is housed in one vast intercomnected building. At noon the students congregate in two

${ }^{5}$ This issue will be elaborated upon in the subsection Internet Service Providers' (ISP's) Responsibility. cafeterias [21]. It is reasonable to assume that Gill deliberately chose this location in order to kill as many people as possible.

\section{Kimveer Gill's Mental Condition as Reflected through His Blog}

Kimveer Gill was a depressed and troubled young man. He was an unemployed loner who lived in his parents' basement in the Montréal suburban neighborhood of Laval [17]. He lived most of his last months in the virtual world of a website named VampireFreaks.com, dedicated to Goth culture.

Kimveer Gill's posts to the VampireFreaks.com website reveal his disturbed nature and provide an insight into his predictable end:

1) His screen name was Fatality666 [22].

2) His favorite video game was Super Columbine Massacre. The player becomes Dylan Klebold or Eric Harris and embarks on a cartoon slaughter, walking through Columbine High School shooting students and teachers [23]. "Work sucks...school sucks...life sucks... what else can I say?" wrote Gill, maintaining, "Metal and Goth kick ass. Life is a video game; you've got to die sometime” [24].

3) His profile reveals his likes and dislikes, for example: Achieve This Year-Stay Alive; How do you want to Die-like Romeo and Juliet-or-in a hail of gunfire; [25] Favorite Movie-Natural Born Killers [26]; Favorite Weapon-Tec-9 semi-automatic handgun (Gill noted that this was an illegal weapon in Canada) [27].

4) On his profile Gill described himself: "His name is Trench. You will come to know him as the Angel of Death...He is not a people person. He has met a handful of people in his life who are decent. But he finds the vast majority to be worthless, no good, conniving, betraying, lying, deceptive” [27].

5) Gill uploaded more than 50 pictures to his page on VampireFreaks.com. Those pictures depicted him dressed like his heroes from Columbine, in a long black trench coat and matching boots, carrying various weapons. In one of the pictures, entitled "You're next", he was seen pointing a handgun at the camera [28]. In another picture he held a sign in order to deliver a message_- "My Gothic Princess Leaves a Trail of Tears. God Has Forsaken Her. God Will Pay” [23]. In his last photo on the VampireFreaks blog, he was wearing his signature trench coat and holding up an automatic weapon with the text message "ready for action" [29].

6) On his virtual tombstone he wrote "Kimveer-Lived fast. Died young. Left a mangled corpse” [30].

7) Gill sent many posts to VampireFreaks; sometimes he would post entries every fifteen minutes. He wrote: "I love VampireFreaks. This is my new home. I shall reside here till the day I die” [31]. Reading excerpts from his 
blog exposes the psychotic personality of a man who was obsessed with hate, death, and guns. For example, on March 15, 2006, Gill wrote:

"I hate this world

I hate the people in it

I hate the way people live

I hate god

I hate deceivers

I hate betrayers

I hate religious zealots

I hate everything

I hate so much

(I could write 1000 more lines like these, but does it really matter, does anyone even care)

Look what this wretched world has done to me" [32].

8) His role models were outlaws such as Bonnie and Clyde, as well as Romeo and Juliet-couples who disregarded societal norms and had died tragic deaths as a result. He admired the Germans, especially Adolf Hitler, and wrote one entry in German: "I will crush my enemies and eliminate them" [30].

9) About two hours before the rampage, Gill wrote on the site he had been drinking whiskey in the morning ("mmmmmm, mmmmmmmmm, good!!") and described his mood the night before as "crazy" and "postal" [33].

In another post he wrote "Give them what they deserve before you go." The word "them" referred to a vast array of people, places and things. Among his most hated things were comedies, governments, sunlight, and country music [32,34]. Gill expressed loathing towards authority figures such as police, teachers, and principals; he singled out "jocks" for high school bullying [32]. Further more, nine months before his rampage he wrote specifically that the day in which he planned to seek revenge would be grey, "A light drizzle will be starting up" [27]. Indeed, such was the weather on the day of his rampage.

Gill did not restrict his violent thoughts to his blog on VampireFreaks. He posted various disturbing and distressing comments on other websites as well. Gill's dark attitude towards the world was confirmed by personality tests he took on the Internet: A test named "Evil-O-Meter" rated him as "pure Evil". Another quiz, "Which dictator are you?" suggested that his personality was consistent with Adolf Hitler's personality. A personality test based on one of his favorite video games, Postal, rated him as having an $84 \%$ chance of "going postal" (which is to say, being involved in a violent massacre) and an $86 \%$ chance of killing someone. These outcomes were accompanied by a recommendation to seek professional help immediately [17]. A police source commented in the aftermath of Gill's rampage: "It was very obvious his state of mind was deteriorating greatly over the last three weeks" [32].

All of the above materials were visible and easily ac- cessible on the VampireFreaks site. Possibly because of this openness, Gill thought the police was after him. In February 2006, on his blog he wrote, "I know you're watching me mother f-----s. I laugh at thee. There is nothing you can do to stop me. HA HA HA HA HA...” [35] Later that month he claimed that officers were pretending to be "nice little Goth girls" as part of their surveillance. [36] Unfortunately, the police did not monitor Gill's actions. If they had, then the policemen would have undoubtedly come across Gill's explicit threat: "Turn this f---ing world into a graveyard/Crush all those who stand in your way/Let there be a river of blood in your wake/ Walk through that river with pride” [36].

\section{VampireFreaks.com}

The VampireFreaks website was founded in 1999 by a Brooklyn resident, Jethro Berelson, who calls himself "Jet". The site claims to have 600,000 - 700,000 members and millions of entrances [32]. VampireFreaks relates to a blood-lusty subculture of would-be vampires who are distinct from the more pacifist Goths [23,37]. This website features web logs and online journals by people with usernames such as SuicideOfLove, TeenageOddity, RottingNails, RazorBladeChris, DrowningInBlood, WiltedBlood and LoveInTheBedOfRazors. Apparently, quite a few of its members share feelings of depression, lonelyness and anger mixed with gallows humor [38]. Some of the website members are obsessed with blood, pain, rape, S\&M and necrophilia [37,39]. One user explains: "It cannot be denied that many people who share our lifestyle are fascinated by blood and death but virtually none of us would ever do anything to hurt another person" [40]. This statement is not altogether accurate.

VampireFreaks serves as a virtual meeting place for Goths, a place where they can share a sense of community and belonging. Gill belonged there more than he did to anything in his real life. He pledged his allegiance to Goth culture on VampireFreaks.com, liked the black clothing, edgy music, macabre poetry, Mohawk spiky hair and the pervading spirit of social alienation [37].

Kimveer Gill was not the first criminal over the last few years who was connected to VampireFreaks.com. In 2005, three teens were prosecuted for the slaying of Jonathan, the 12-year-old brother of one of the three and attempting to kill his stepfather. The killer brother was a wannabe vampire with a fetish for blood sipping as sexual foreplay [22]. Jonathan was stabbed 71 times. During the trial, it was revealed that the 16-year-old former girlfriend of one of the killers blogged on VampireFreaks. The girl's posted profile on VampireFreaks listed among her likes "blood, pain... cemeteries and knives" [40]. She was the prosecution's star witness, and downplayed her interest in vampire fetishism when she testified at the 
jury trial [41]. When her VampireFreaks postings surfaced later, it was found that she had perjured herself in court, and the judge declared a mistrial. A second trial found the men guilty [41,42].

In April 2006, a 12-year-old girl who called herself “The Runaway Devil” and her 23-year-old boyfriend, Jeremy Allan Steinke, were charged with the triple murders of Marc Richardson, 42, his wife Debra, 48, and their son Jacob, $8[36,43,44]$. They both were part of the VampireFreaks.com community, where the girl used the online name of Killer-Kitty-X, described herself in her profile as "bisexual," "wiccan" and "insane," and confessed to like "hatchets, serial killers and blood" [45]. The 7th grade student had abandoned her clean-cut look for a darker, Goth style, with heavy eyeliner and nail polish. In one picture on her website, she posed holding a gun to the camera as she pledged her love for Goth, punk, dark poetry and death metal music [46]. Her boyfriend matched her likes as he preferred "blood, razor blades and pain” [47]. He presented himself as a 300-year-old werewolf who liked the taste of blood [36]. Steinke and his 12-year-old girlfriend each had personal pages on VampireFreaks and made chilling postings prior to the slayings of the Richardson family [48]. One message, from Steinke's souleater52 account, made reference to “doing morbid stuff to others! ... Which I'm going to do this weekend," days before the Richardson family was killed [49,50].

After the Richardson triple killing, many Goths were irritated by the subculture's being portrayed by the media as dangerous; they took pains to say that their interest is a harmless one [51,52]. The same month of April 2006, however, VampireFreaks was once again on the news. Eric Fischer, a 23-year-old man, described as a Goth from New York, was arrested after showing up at a cemetery expecting to have sex with a 13-year-old girl he met on VampireFreaks. It was the second alleged incident in which Fischer used the site to lure young girls. In March 2006, he had been arrested on rape charges after attacking a 16-year-old girl he had met on the website [50].

In June 2006, three young men were sentenced for a deliberate fire that destroyed the 105-year-old Minnedosa United Church, in Minnedosa, Manitoba. One had posted his profile on VampireFreaks. Referring to Jesus Christ, he wrote: "If he comes back, we'll kill him again" [36, 53]. In February 2009, 36-year-old Robert Earl Hogan of Hillsboro, Oregon was sentenced to 10 years in federal prison for luring a 14-year-old girl met on Vampirefreaks in order to have sex with her [50]. In August 2009, Derek Campbell, 28, of Toronto was charged for meting a 13-year-old girl on VampireFreaks and taking video of her in sexual positions. The same week, the police arrested Arthur Brown of Toronto, a 44-year-old bisexual vampire freak, for sexual assault of a 14-year-old girl whom he met on the website [54].

Parry Aftab, head of Wired Safety (a volunteer watchdog organization that monitors websites) said the Goth culture is not at issue in the discussion of Gill's crime, but that the role of the VampireFreaks site cannot be easily discounted. She said her organization has con- tacted VampireFreaks.com repeatedly and received countless complaints about its content from parents and from teens who were harassed and abused. Aftab said: "I think the site is starting to breed a different Goth...many of the kids who are highly troubled and those who are making trouble for others, are gravitating to that site... the major problem...is that it seems to normalize aberrant behavior" [55,56]. Aftab maintained, "Some of these kids who are troubled know they'll only get attention on there if they do something different than everyone else. You have to up the ante" [36]. Websites like Vampire-Freaks. com create virtual communities and put people in touch. On such sites, when someone brags that he was doing something outrageous, people around him often congratulate him, sometimes encourage this sort of behavior [36]. After another incident that required police intervention in which a "Vampire" arranged to meet a teen in a graveyard via the VampireFreaks website, Suffolk County Police Deputy Inspector Mark Griffiths said that VampireFreaks.com attracts people “on the fringe”, people who are lonely and depressed [57].

\section{Internet Warnings}

Often, killers do not just snap and start shooting. Kimveer Gill was a walking bomb ready to explode, filled with growing rage and hatred. Kevin Cameron, a traumatic stress expert, explained that "Serious violence is an evolutionary process" [53]. The process begins with bitterness, degenerates into anger and rage, and if there are no mitigating circumstances, the wrath might end with a brawling explosion. People need to vent their hostility, their acrimony, their anger. They provide signs, hints. They find it difficult to contain all these boiling emotions inside them. In the Internet age, it is convenient to vent into the virtual world. If not stopped, said Canadian anthropologist Elliott Leyton, the end result of "those who had looked upon their own lives and pronounced them unlivable", and then decide to exact revenge for which they were willing to sacrifice their lives, is gore, death and suicide [58].

The April 1999 Columbine slaughter that left 12 people dead set the benchmark for Gill and other killers. It had also set the tone for them regarding the use of the Internet to publicize their notorious thoughts and their intended evil schemes. After Columbine, a pattern has emerged: boiling criminals are venting their rage and vile 
intentions on the Internet.

On January 8, 2005 Ricky Rodriguez killed a prominent former member of the Christian sect, The Family International, and then committed suicide. Rodriguez recorded a videotape that has been featured on several Internet sites, including ABC.com and CNN.com. In the video he said: "Anger does not begin to describe how I feel about these people. I've seen how ugly humans can get... There's this need that I have. ... It's a need for revenge. It's a need for justice" [59].

\section{Internet Service Providers' (ISP’s) Responsibility}

Jet, the VampireFreaks.com owner and operator, responded to Gill's murderous rampage almost immedi- ately. He relieved himself of any responsibility, saying: "Just because someone goes around shooting people and happens to be a member of VampireFreaks, doesn't mean that this website has influenced him to do such a horrible thing" [60]. Jet also said that the website frowns on illegal behavior and bans nudity, hatred and Nazi paraphernalia [36].

In this context it is important to note that after the murder, Kimveer Gill's profile was taken off VampireFreaks.com. Jayson Gauthier, the provincial police force's spokesman, said that an American police force had demanded the shutdown after a request from the Canadian authorities [61]. This measure should have been taken before the murder. Gauthier also said that no police department had been aware of Gill until the shootings [62].

Jet of VampireFreaks.com claimed he was doing whatever he could to prevent the posting of offensive or dangerous material: "We do monitor user messages and profiles for violent, hateful and offensive material. However on a site with over 600,000 users, it is impossible to monitor everything on the site" [62]. Let us quote in full what the site moderator wrote:

\section{Montreal shooting-*September 14, 2006*}

So yes there's been a lot of press lately regarding a shooting in Montreal, where the person involved was a member of this site. I offer my condolences to the victims and their families; it really is a tragic event. Human life is very precious and it's sad that there are people out there who commit such terrible crimes. This is very devastating and I know people are looking for answers, somewhere to point the finger, trying to figure out why this has happened. I'm sure the person who did this was a very troubled and emotionally unstable individual. We do not condone or influence this type of behavior in any way. The criminal was actually a member of other sites such as "MySpace", yet somehow our site is the only one being named. Many people do not understand our scene and would like to point the finger at us, but the Goth scene is a very friendly, nurturing, non-violent community. We are very supportive of our users and do not condone any illegal activities. Please do not condemn us for the wrongdoings of one individual. We have an excellent team of administrators who moderate the site, and a useful system which allows all users to report illegal and suspicious activity. Thank you to all the users who continue to help us moderate the site. I do think this event is a tragedy, but I feel that this site is wrongly being associated with the shooting. I'm sure this kid also had accounts on various other sites, but the media likes to associate crimes with gothic culture because it makes a better story for them. So, I just want to ask our members to really try to set a good example to the world, to show that we really are caring, responsible, non-violent people. In fact I believe we are more mature and responsible than other scenes, in that we value intelligence, part of Goth culture is thinking for yourself and being more aware of the world, rather than just following the mainstream trends. Don't let a few bad seeds ruin our reputation, we are a great community. On another note, due to all the media coverage, the site is slower than usual, but I'm trying my best to keep the site running smoothly and it should be back to normal after the media hype dies down over the next day or two [62].

VampireFreaks.com is a busy site with hundreds of thousands of postings. Some effort is needed for moderators of such large sites to monitor the heavy traffic. A web expert who worked for Yahoo! in monitoring Yahoo! groups told Raphael Cohen-Almagor that a small number of experts who specialize in social networking could devise batches of programs to look for illegal material and remove it. The interviewed expert did this for Yahoo! in its struggle against child pornography [63]. Similarly, Marc Rotenberg, President of the Electronic Privacy Information Center, said that the capability to monitor the Internet is greater than what most people assume. It is a question of will, not of ability [64,65].

Thus, it is possible to monitor traffic on large websites. It is a question of priorities in allocating resources for monitoring. At present, VampireFreaks is not exceptional in its reluctance to monitor sites and relieve itself of responsibility. Most ISPs shy away from assuming such responsibility, as it is the easiest and most profitable path to pursue, but this attitude may change. It is already changing in the spheres of child pornography and terrorism.

\section{Studying Social Networks}

Social networks sites (SNSs) have become a main academic topic in the last few years. There is a growing body of research concerning SNSs stemming from diverse disciplines and using various methodologies. In 
2007, JCMC_-Journal of Computer-Mediated Communication has dedicated a special volume to Social Networks Sites [66,67]. Still, there is a lot that we yet need to learn about the way people are communicating via such sites and what can be done to ensure that social networks won't become anti-social.

Boyd and Ellison define social network sites as web based services that allow individuals to 1) construct a public or semi-public profile within a bounded system; 2) articulate a list of other users with whom they share a connection; 3) view and traverse their list of connections and those made by others within the system. Each site is unique in its platform and uses different nomenclature [68]. In this context, it is important to distinguish between networking and SNS. While the term networking usually refers to the art of creating new relationships, mostly among strangers, SNS' primary aim is to enable users to visualize and display their existing social networks [69].

When thinking of social networks we instantly refer to Facebook, the most well-known social network developed in 2004 by Mark Zuckerberg and Eduardo Saverin, two Harvard undergraduates. Facebook started as an internal Harvard SNS. In addition to Facebook, there are hundreds of social networking websites ${ }^{6}$, which can be categorized by their target audience, geographic distribution (some are local, some are national and some are worldwide) and networking purpose: Business Networking Sites; Common Interest Networking Sites; dating network sites, etc.

Boyd and Ellison [69,70] mention four research pivots: 1) Impression Management and Friendship Performance [69]; 2) Networks and Network Structure [71-74]; 3) Online vs. Offline Connections [75,76]; 4) Privacy Issues $[77,78]$. A psychological research area which deals with risky behaviors people-especially youth-on SNSs is timely and important [79-81]. Broadening research in this area can assist law-enforcement agencies as well as psychologists, psychiatrists and education people identifying risky situations and preventing hideous crimes as those discussed in this paper.

\section{Conclusions}

The Internet is a vast ocean of knowledge, data, ideologies and propaganda. It contains some of the best products of humanity, and some of the worst ones. It has served killers. It should also serve the positive elements in society to prevent murders.

The important lesson learned from the above tragic in-

\footnotetext{
${ }^{6}$ See Alphabetic list of major active SNS

http://en.wikipedia.org/wiki/List_of_social_networking_websites; Categorized list of social media and SNS-

http://traffikd.com/social-media-websites/. Both lists include VampireFreaks.com.
}

cidents is the urgent need to monitor websites which are known for their problematic nature to prevent prospective tragedies. The police must develop the ability to monitor a suspect's Internet activity.

The ascending frequencies in which these events happen require action on the international level. Since human lives are at stake, preemptive measures could prevent the translation of murderous thoughts into murderous actions. Such cooperation, through voluntary and organized operations, must include all sectors: governments, law-enforcement agencies, civil society organizations and the business sector (especially Internet Service Providers, website administrators and owners) as well as civil society groups in order to be successful.

We suggest monitoring the Internet for problematic websites that are used to promote violence; devising monitoring mechanisms for these websites; publishing overviews and reports; exchanging information to enhance the effectiveness of operations; lobbying for international legislation, helping support groups and institutions that want to set up tip lines, and raising public awareness by providing information to interested parties.

\section{REFERENCES}

[1] V. Bush, “As We May Think,” The Atlantic Monthly, Vol. 176, No. 1, 1945, pp. 101-108. http://www.theatlantic.com/doc/194507/bush

[2] J. C. R. Licklider, "Man-Computer Symbiosis,” IRE Transactions on Human Factors in Electronics, Vol. HFE-1, 1960, pp. 4-11. http://groups.csail.mit.edu/medg/people/psz/Licklider.html

[3] D. C. Engelbart, "Augmenting Human Intellect: A Conceptual Framework,” Summary Report, AFOSR-3223, Stanford Research Institute, Menlo Park, 1962. http://bootstrap.org/augdocs/friedewald030402/augmentin ghumanintellect/AHI62.pdf

[4] V. G. Cerf, "First, Do No Harm,” Philosophy \& Technology, Vol. 24, No. 4, 2011, pp. 463-465. http://www.ibiblio.org/pioneers/cerf.html

[5] J. C. R. Licklider and R. W. Taylor, "The Computer As a Communication Device," Science and Technology, Vol. 76, 1968, pp. 21-38.

[6] L. Kleinrock, "Information Flow in Large Communication Nets," Ph.D. Thesis, Massachu-Setts Institute of Technology, Cambridge, 1961. http://www.lk.cs.ucla.edu/LK/Bib/REPORT/PhD

[7] P. Baran, "On Distributed Communications Networks," IEEE Transactions on Communication Systems, Vol. 12 No. 1, 1964, pp. 1-9. http://www.ibiblio.org/pioneers

[8] R. Cohen-Almagor, “Internet History,” International Journal of Technoethics, Vol. 2, No. 2, 2011, pp. 45-64. doi:10.4018/jte.2011040104

[9] S. Cohen, "Folk Devils and Moral Panics," Routledge, London, 1987, p. 9. 
[10] C. Critcher, "Moral Panics and the Media: Issues in Cultural and Media Studies," Open University Press, Buckingham, 2003.

[11] C. Krinsky, "Moral Panics over Contemporary Children and Youth,” Ashgate, Aldershot, 2009.

[12] E. Goode and N. Ben-Yehuda, "Moral Panics,” WileyBlackwell, Chichester, 2009.

[13] "Moral Panic". http://www.mediaknowall.com/violence/moralpanicnotes. html

[14] S. Livingstone and M. Bober, "UK Children Go Online: Final Report of Key Project Findings," Economic and Social Research Council, London, 2005.

http://www.lse.ac.uk/collections/children-go-online/UKC GO_Final_report.pdf

[15] Council of Europe, "Convention on Cybercrime," 2008. http://cis-sacp.government.bg/sacp/CIS/content_en/law/it em06.htm

[16] US Department of Justice, “Computer Crimes and Intellectual Property Section: International Aspects of Computer Crime". http://www.cybercrime.gov/intl.html\#Vb1

[17] J. Wong, "Get Under the Desk,” Globe and Mail, 16 September 2006, pp. A8-A9.

[18] D. Renaud, “Gunman Showed No Pity to Girl,” Toronto Sun, 15 September 2006, p. A3.

[19] T. T. Ha, I. Peritz and A. Picard, "Shooter Had Brief Military Service,” Globe and Mail, 16 September 2006, p. A9.

[20] Encyclopedia, “Anastasia Rebecca de Sousa,” 2006. http://www.statemaster.com/encyclopedia/Anastasia-Reb ecca-de-Sousa

[21] A. Picard, "Gunman Shot Student Again and Again," Globe and Mail, 15 September 2006, p. A8.

[22] J. Ajit, "Raging, Alienated, Gill Was a Walking Time Bomb,” India Abroad, 22 September 2006, p. A1.

[23] N. Pona, "Net Violence Unchecked," Toronto Sun, 15 September 2006, p. 4.

[24] C. Gibson, “A Closer Look; A Mind of a Killer,” $A B C$ News Transcripts, 14 September 2006.

[25] T. Harris, H. Collins, B. Starr, A. Chernoff, R. Kaye, A. Koppel, D. Sieberg, S. Gupta, A. Cooper, K. Arena and H. Gorani, "Rounding Up the Enemy; Lone Gunman Opens Fire on Students in Montreal,” CNN, 14 September 2006.

[26] “Profile Posted by Kimveer Gill," National Post, 15 September 2006, p. A4.

[27] P. Gombu, "Web Diary, Photos Reveal Angry Man Who Loved Guns and Hated People,” Toronto Star, 14 September 2006, p. A1.

[28] P. Couvrette, “Rampage Shooter an Angry Loner,” Pittsburgh Post-Gazette, 15 September 2006, p. A4.

[29] Toronto Sun, 15 September 2006, p. A4.

[30] "Montreal Shooting-The Blog: Excerpts 'I Hate This World...I Hate So Much',” National Post, 15 September 2006, p. A4.

[31] P. Couvrette, “College Gunman Liked Columbine Role-
Play,” Sun-Sentinel, 15 September 2006, p. 20A.

[32] “Killer Likened Life to a Video Game," Globe and Mail, 15 September 2006, p. A9.

[33] S. Montgomery and J. Heinrich, “Acting out His Fantasy: Dawson College Gunman Posted Visions on His Blog of What He Enacted Wednesday," Edmonton Journal, 15 September 2006, p. A3.

[34] “A Blog of Violence and Death,” Newsday, 15 September 2006, p. A32.

[35] S. Agrell and P. Cherry, "Blogs Reveal a Deteriorating Mind, Police Say,” National Post, 16 September 2006, p. A9.

[36] S. Agrell, “Troubled Kids 'Gravitating' to Vampire Site,” National Post, 15 September 2006, p. A6.

[37] M. Mandel, “Out for Blood,” The Toronto Sun, 24 September 2006, p. 5.

[38] M. Philip and C. Alphonso, "The Geeks at the Back on Computers," Globe and Mail, 15 September 2006, p. A9.

[39] R. Remington and S. Zickefoose, "12-Year-Old Faces Judge in Triple Murder: Boyfriend, 23, also Accused in Deaths of Medicine Hat Family," Edmonton Journal, 26 April 2006, p. A2.

[40] K. Connor, “T.O.’s Vampires Out for Blood,” The Toronto Sun, 6 March 2005, p. 36.

[41] C. Blatchford, “Jonathan Trial Aborted,” 16 February 2005. http://www.theglobeandmail.com

[42] P. Small, "Teen Found Guilty in Beating Death of Brother,” Tribe.ca, 27 February 2006.

http://www.tribemagazine.com/board/showthread.php?t= 111821

[43] M. Mandel, “Match Made in Hell,” Edmonton Sun, September 17, 2006, p. 7.

[44] S. Agrell, “'Vampire’ Blog Derailed Murder Trial: Boastful Postings Cast Doubt on Credibility of Star Crown Witness,” Ottawa Citizen, 17 February 2005, p. A6.

[45] L. Robertson, "Web Links to Shooting," CTV Television, 14 September 2006.

[46] P. Fong, “Girl Apologized to Dead Family,” Toronto Star, 11 July 2007, p. A4.

[47] H. Lake, "Linking the Internet and Goth Culture to the Medicine Hat Murders may Be Jumping to Conclusions, Experts Caution,” The Ottawa Sun, 27 April 2006, p. 5.

[48] J. Stevenson, "Slain Boy Found in His Bed Surrounded by Blood Soaked Toys,” Canadian Press Newswire, 12 June 2007.

[49] I. Austen, "Gunman at Montreal College Left Dark Hints of Rage Online,” The New York Times, 15 September 2006, p. 10.

[50] I. MacLeod, "Vampire Culture Gets Another Black Mark after Shooting: Website Linked to Medicine Hat Slayings,” The Calgary Herald, 15 September 2006, p. A3.

[51] S. Zickefoose, "Girl Accused in Slayings Back in Court Today,” The Calgary Herald, 1 May 2006, p. B1.

[52] R. Remington and S. Zickefoose, "Runaway Devil: How Forbidden Love Drove a 12-Year-Old to Murder Her Family,” McClelland \& Stewart, Toronto, 2009. 
[53] “'Vampire' Meets 'Teen' in Graveyard,” United Press International, 28 April 2006.

[54] T. Reynolds, "Man Sentenced for Luring Teen over Vampirefreaks," Trench Reynolds Crime News, 18 February 2009.

http://www.crimene.ws/2009/02/man-sentenced-for-lurin g-teen-over.html

[55] K. Connor, “'Vampire' Accused of Child Assault,” The Toronto Sun, 21 August 2009. http://cnews.canoe.ca/CNEWS/Crime/2009/08/21/105457 26-sun.html

[56] E. Morningstarr, "Vampire Freak Arrested for Child Sex Crime," 22 August 2009.

http://www.themorningstarr.co.uk/2009/08/22/vampire-fr eak-arrested-for-child-sex-crime

[57] M. DuBois, "Parry Aftab of Wiredsafety.org Discusses Monitoring of Web Sites that Could Influence Violent Behaviors among Its Users," CBS News Transcripts, 16 September 2006.

[58] E. Strachan, “Gill, Games, Goth and Guns,” Pembroke Observer, 16 September 2006, p. 18.

[59] C. Blatchford, "Social Analysis of Violent Acts Could Be Key to Prevention,” The Globe and Mail, 15 September 2006, p. A10.

[60] P. Swanson and K. Nguyen, "Web Rants Raise Red Flags for Violence: But Police Can Do Little to Prevent Attacks," The Gazette, Colorado Springs, Colorado, 16 December 2007.

http://www.gazette.com/articles/people-30945-murray-we b.html

[61] J. Mahoney, “Killer's Grim Net Warning,” Daily News, New York, 15 September 2006, p. 33.

[62] I. Austen, "Gunman at Montreal College Left Dark Hints of Rage Online," The New York Times, 15 September 2006, p. A9-A10.

[63] http://www.vampirefreaks.com

[64] "Discussion with a Research Specialist," George Washington University, Washington DC, 12 June 2008.

[65] S. Silberman, "The United States of America v. Adam Vaughn,” Wired, 10 October 2002. http://www.wired.com/wired/archive/10.10/kidporn.html

[66] "Interview with Marc Rotenberg, President of the Electronic Privacy Information Center," Washington DC, 2 May 2008.

[67] R. Cohen-Almagor, "Responsibility of and Trust in ISPs," Knowledge, Technology and Policy, Vol. 23, No. 3, 2010, pp. 381-397.

[68] “Special Theme: Social Networks Sites,” Journal of Computer-Mediated Communication, Vol. 13, No. 1, 2007. http://jcmc.indiana.edu/vol13/issue1

[69] D. M. Boyd and N. B. Ellison, "Social Networks Sites: Definition, History and Scholarship”, Journal of Computer-Mediated Communication, Vol. 13, No. 1, 2007. doi:10.1111/j.1083-6101.2007.00393.x http://jcmc.indiana.edu/vol13/issue1/boyd.ellison.html

[70] M. F. Wright and Y. Li, "The Associations between Young
Adults’ Face-to-Face Prosocial Behaviors and Their Online Prosocial Behaviours," Computers in Human Behavior, Vol. 27, No. 5, 2011, pp. 1959-1962.

[71] J. B. Walther, B. Van Der Heide, S. Y. Kim, D. Westerman and S. T. Tong, "The Role of Friends Appearance and Behavior on Evaluations of Individuals on Facebook: Are We Known by The Company We Keep?” Human Communication Research, Vol. 34, No. 1, 2008, pp. 28-49.

[72] D. Boyd, "Taken out of Context: American Teen Sociality in Networked Publics.” Ph.D. Thesis, University of California-Berkeley, California, 2008. http://www.danah.org/papers/TakenOutOfContext.pdf

[73] S. Zhao, S. Grasmuck and J. Martin, "Identity Construction on Facebook: Digital Empowerment in Anchored Relationships," Computers in Human Behavior, Vol. 24, No. 5, 2008, pp. 1816-1836. doi:10.1016/j.chb.2008.02.012 http://astro.temple.edu/ bzhao001/Identity\%20Constructi on\%20on\%20Facebook.pdf

[74] B. Hogan, "Analyzing Social Networks via the Internet," In: N. Fielding, R. M. Lee and G. Blank, Eds., Sage Handbook of Online Research Methods, Sage, Thousand Oaks, 2008, pp. 141-160. doi:10.4135/9780857020055.n8

[75] D. Boyd, "Why Youth (Heart) Social Network Sites: The Role of Networked Publics in Teenage Social Life,” In: D. Buckingham, Ed., Youth, Identity and Digital Media, Massachusetts Institute of Technology Press, Cambridge, 2008, pp. 119-142.

[76] A. Lenhart and M. Madden, "Teens, Privacy and Online Social Networks," Pew Internet \& American Life Project, 18 April 2007.

http://www.pewinternet.org/Reports/2007/Teens-Privacyand-Online-Social-Networks.aspx

[77] S. Barnes, "A Privacy Paradox: Social Networking in the United States,” First Monday, Vol. 11, No. 9, 2006. http://firstmonday.org/htbin/cgiwrap/bin/ojs/index.php/fm /article/view/1394/1312

[78] M. J. Hodge, “The Fourth Amendment and Privacy Issues on the 'New' Internet: Facebook.Com and My space. Com,” Southern Illinois University Law Journal, Vol. 31, 2006, pp. 95-123.

http://www.law.siu.edu/research/31fallpdf/fourthamendm ent.pdf

[79] K. J. Mitchell and M. Ybarra, "Social Networking Sites: Finding a Balance between Their Risks and Benefits," Archives of Pediatrics \& Adolescent Medicine, Vol. 163, No. 1, 2009, pp. 87-89.

[80] M. A. Moreno, M. R. Parks, F. J. Zimmerman, T. A. Brito and D. A. Christakis, "Display of Health Risk Behaviors on Myspace by Adolescents," Archives of Pediatrics \& Adolescent Medicine, Vol. 163, No. 1, 2009, pp. 27-34.

[81] M. Barbovschi, "Meet the 'E-Strangers'. Predictors of teenagers’ Online-Offline Encounters,” Cyberpsychology: Journal of Psychosocial Research on Cyberspace, Vol. 3, No. 1, 2009.

http://www.cyberpsychology.eu/view.php?cisloclanku=2 009061603\&article $=4$ 